\title{
A new quantitative sediment corer for sampling invertebrates across the mud water interface and soil of shallow rice field
}

\author{
H. Soumille ${ }^{1}$ \\ A. Thiéry 12
}

Keywords : Zoobenthos, chironomids, mud, rice field, sediment corer, vertical profile.

A new corer is described which may be used in sediments of shallow standing waters, such as in rice fields, and which facilitates the study of the vertical distribution of the invertebrate fauna at $2 \mathrm{~cm}$ depth intervals. Its small surface area permits quantitative sampling of the sediment-dwelling fauna, particularly the chironomid larvae, around the roots of rice-plants. Results are presented and the efficiency of the sampling method is discussed.

Un nouveau carottier pour échantillonner quantitativement les invertébrés de l'interface eau-vase et du sol d'une rizière

Mots clés : Zoobenthos, Chironomidés,vase, rizière, carottier, profil vertical.

Description d'un carottier adapté aux eaux stagnantes peu profondes telles que les rizières et qui permet d'étudier la stratification de la faune invertébrée par tranches de $2 \mathrm{~cm}$ d'épaisseur. La surface réduite de l'appareil permet d'échantillonner quantitativement la faune fouisseuse, et plus particulièrement les larves de Chironomidés, dans la rhizosphère. Des résultats sont présentés et l'efficacité du carottier est discutée.

\section{Introduction}

In shallow wetlands most quantitative studies dealing with water fauna use different sampler devices such as open cylinder (Heurteaux \& Marazanof 1965, Pont 1983) or other techniques when biotopes are occupied by aquatic macrophytes (Aguesse 1955, MacCauley 1975). In the case of mud sampling different fresh sediment samplers were used (Crossland 1962, Armitage 1979), as corers (see Aguesse 1955 pl. 7, a review in Giani 1974, Downing 1984, Fuller \& Butman 1988). As pointed by Darby (1962) the problem of a sampling method for obtaining accurate quantitative data in rice field was never really solved. Only the shallow-water bottom sampler by Kellen (1954) proved to be satisfactory. However, one of the main disad-

1. Laboratoire de Biologie Animale-Hydrobiologie, (U.P.R.E.S. E.A. $n^{\circ} 2152$, Faculté des Sciences, 33 rue Louis Pasteur, F-84000 Avignon, France.

2. Corresponding author. vantages of these corers was that they were not able to take into account evidence to the bottom invertebrates stratification. During a field evaluation of the rice plant injury by aquatic invertebrates in Camargue, particularly by chironomid larvae, a corer was developed and tested in order to sample the invertebrates at different levels of the rice plant: in water, at water-mud interface and along a fine-scale vertical profile in sediments. The corer described here is adapted to a rice field with a maximum depth of water less than $25 \mathrm{~cm}$.

\section{Description and operation}

The corer consists of an assemblage of tubes of three different lengths (Fig. 1a). One with a length of $20 \mathrm{~cm}$ (sampling of water, in aluminium AU4G) (Fig. 1b), a series of $2 \mathrm{~cm}$ long tubes (in aluminium), or rings (Fig. 1c), (their number is variable in function of the required depth in soil, i. e., 10 in this study), and a final tube with a cutting edge (in stainless steel) (Fig. 1d). Aluminium and stainless steel are used to avoid corrosion. All tubes are $3 \mathrm{~cm}$ in internal diameter, corresponding to a surface of $7 \mathrm{~cm}^{2}$, and have a male thread at its upper side and a female thread at its lower part. 
Their wall is $6 \mathrm{~mm}$ thick for core tube rigidity and threading. The inner diameter of tubes has been chosen in relation to two facts: 1) soft sediments can be lost when the opening of the tube is superior to $5 \mathrm{~cm}$ (Douglas 1988$)$; 2) the corer is mainly used at the neighbouring of the rhizosphere, in order to quantify the injury caused to roots by chironomid midges larvae, and so, it must be straight, to avoid any damage to plants. Each $2 \mathrm{~cm}$ ring corresponds to a $14 \mathrm{~cm}^{3}$ volume of sampled soil. For details of construction see Fig. 1. In operation a polyethylene part is placed on the upper tube in order to avoid damage during its knock inside the soil (Fig. 2b). The corer is drived in up to the lower limit of the longer tube (water-mud interface), and must be extruded with a clockwise screwing movement. The deeper soil layers, rich in clay, make a plug which keep all the upper layers in the corer. The water contained in the upper part is filtered on a $200 \mu \mathrm{m}$ mesh, and after that each ring is unscrewed and its content was placed in a polyethylene vial containing 10 percent formalin this preservative is known to minimize the lost of weight for invertebrates in biomass evaluations (Howmiller 1978, Senapati \& Dash 1980). At the laboratory, in order to disperse the soil particles from the high clay content (mainly in the strates $-2-20 \mathrm{~cm}$ ), each core is soaked in solution of $10 \mathrm{~g} . \mathrm{L}^{-1}$ sodium hexametaphosphate (sold commercially as Calgon ${ }^{\circledR}$ ) as recommended by Southwood (1978), and slowly agitated with a Gerhardt ${ }^{\circledR}$ agitator during 2 hours. After this pretreatment, the sample is washed on a $200 \mu \mathrm{m}$ mesh and invertebrates were counted under a stereomicroscope. The whole fauna is stored in $\mathbf{1 0}$ percent formalin for future biometric studies.

\section{Performance}

As no stratified corer exists before, no efficient comparison can be made. However, the corer has been used over a complete rice culture season (from April to September 1996). Samples were made every decade, from the flooding time, on 14th May $\left(\mathrm{t}_{0}\right)$, and were noted as $t_{1}$, (ten days after the flooding time), $t_{2}$ (twenty days), etc. up to the crop-day, on 16 September. In the present study, we chose the dates $t_{2}$, on 4 June, and $t_{6}$, on 15 July, as representative examples for testing the accuracy of the method (Figs. 3-5).

\section{Vertical distribution of invertebrates (Fig. 3)}

At $t_{2}$, a total of 230 invertebrates was collected in 9 cores distributed all over the rice field. More than 85 per cent of the fauna are comprised between water column and the $0-2 \mathrm{~cm}$ layer (Fig. 3b). Downward the density gradient declined quickly with depth. No living fauna was found below the $-10-12 \mathrm{~cm}$ layer.
At $t_{6}, 82$ percent of the 169 invertebrates taken in 9 cores were mainly distributed in water and in the first layer $0-2 \mathrm{~cm}$.

The highest averages are found in water and in the water-mud interface.

\section{Distribution patterns of dominant taxa (Fig. 4)}

At $t_{2}$, the densities tended to be highest in water (Orthocladiinae larvae, cladocerans) and in fluid mud, $i$. e., 0-2 cm and $-2-4 \mathrm{~cm}$ (Chironomus plumosus-group) and decreased rapidly up to the $-10-12 \mathrm{~cm}$ layer. Each taxon presents a vertical distribution according to its ecology: for example cladocerans are strictly discovered in water, ostracods are only present in water and water-mud interface, oligochaete worms are only recovered from the upper strates of soil $(0$ to $-6 \mathrm{~cm})$. Midge larvae which are often known to be mud-dwelling forms were found in water and in soil (unidentified Chironomini down to $-6-8 \mathrm{~cm}$, Tanytarsini down to -2$4 \mathrm{~cm}, . .$.$) .$

At $t_{6}$, the populations were less abundant, three taxa being dominant: copepods and ostracods in water and water-mud interface, and oligochaetes in the four first strates of soil. The others taxa were rare and scarcely distributed.

Chironomid midge larvae distribution patterns (Fig. 5)

At $t_{2}$, densities per $10 \mathrm{~cm}^{2}$ show that midge larvae, all taxa gathered, present a peak which occurs in water (Orthocladiinae) and fluid mud (Chironomus plumosus-gr.), and reaches about 100 larvae, while between 2-4 cm layer it only reaches about 20 larvae. Downward densities are very low, no larvae being recorded below $12 \mathrm{~cm}$.

At $t_{6}$, most of the midge larvae have emerged, the densities being very low not reaching 5 larvae per 10 $\mathrm{cm}^{2}$ in the mud.

The vertical profile in Fig. 5a clearly shows the burying behaviour of the Chironomini larvae (gathered unidentified larvae and Chironomus plumosus-gr.). On the other hand no data could be obtained on the behaviour of the Orthocladiinae sampled in water. For this problem, the corer is not suitable.

\section{Discussion}

The stratified corer, described above, gave satisfaction in rice field sampling, its chief advantages being its simplicity, and taking relatively undisturbed cores, at $2 \mathrm{~cm}$ vertical intervals. With this corer, the sediment-water interface is satisfically sampled as the fauna of the different soil layers at different depth. The comparison in ostracods densities between the present 


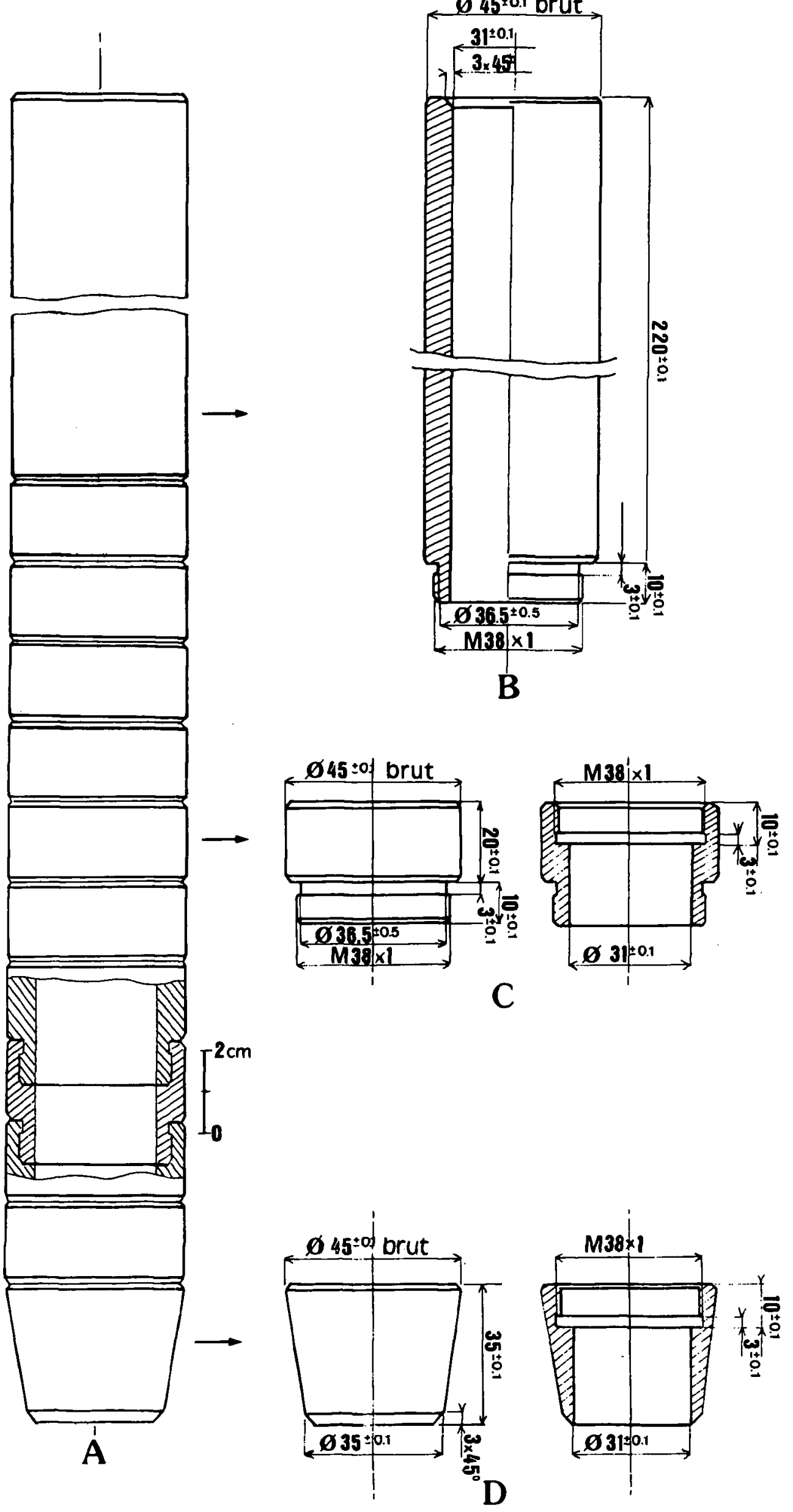

Fig. 1. Sediment corer: A. assembled; B. to D. showing compartments. B. upper tube (aluminium) sampling the water column; C. detail of one mud or soil sampling tube (aluminium); D. lower tube (stainless steel) with its cutting edge.

Fig.1. Plan du carottier: A. assemblé; B. à D. détail des différents composants. B. tube supérieur en aluminium assurant l'échantillonnage de la colonne d'eau; $C$. détail d'une bague en aluminium; D. tube inférieur biseauté en acier inoxydable. 

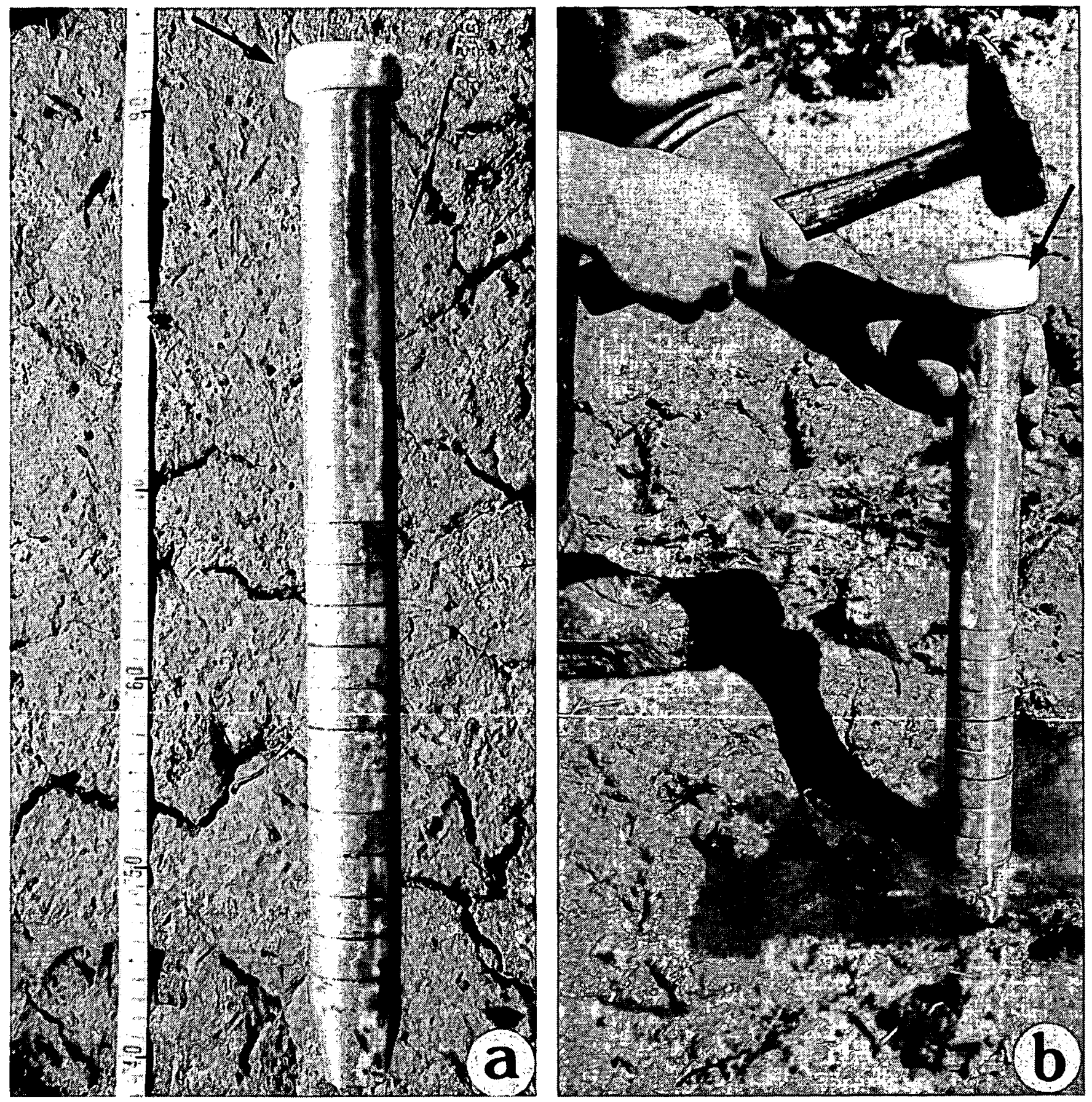

Fig. 2. View of the corer in situ: a. assembled; b. during the coring operation, with the polyethylene part placed on the upper part of the corer (arrow).

Fig. 2. Vue d'ensemble du carottier in situ: a. assemblé; b. en place durant la phase d'enfoncement avec un bouchon de polyéthylène placé à son extrémité supérieure (flèche).

study and that of Pont (1983) in similar biotopes (Table 1), shows that our quantitative method gave densities of the same order and is considered as representative.

This corer had only a limit in not sampling the large swimming invertebrates (waterbugs, beetles...), a bowwave effect due to the small diameter of the tube being detected. This one is limited at water-soil interface resulting from the viscosity of the mud. For a representative sampling of this fauna the open cylinder by Heur-
Table 1. Comparative densities of ostracods (number per $10 \mathrm{~cm}^{2}$ ) in rice fields of the Camargue between the data by Pont (1983) and this study.

Tableau 1. Comparaison des densités d'Ostracodes (par $10 \mathrm{~cm}^{2}$ ) dans les rizières de Camargue entre les données de Pont (1983) et celles de la présente étude.

\begin{tabular}{ccc}
\hline $\begin{array}{c}\text { Sampling date after flooding } \\
\left(=\mathrm{t}_{0}\right)\end{array}$ & Pont (1983) & This study \\
\hline twenty days $\left(\mathrm{t}_{2}\right)$ & 30 & 10 \\
sixty days $\left(\mathrm{t}_{6}\right)$ & 162 & 136 \\
\hline
\end{tabular}



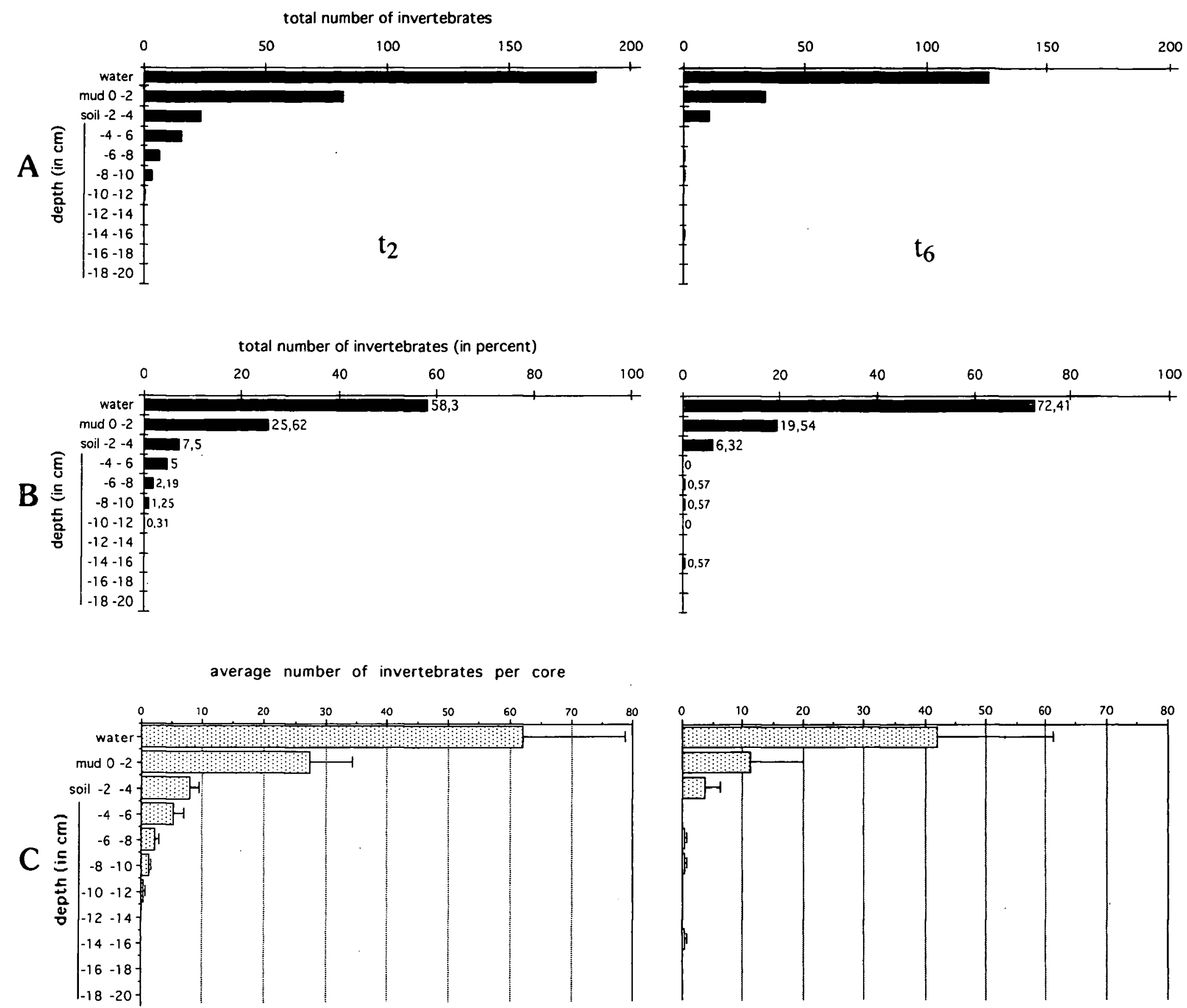

Fig. 3. Vertical profile of invertebrates from a Camargue rice field, on 4 June $\left(t_{2}\right)$, and 15 July $1996\left(t_{6}\right)$ : a. total number of invertebrates (for a detail of the composition of the biocenose see Fig. 4); b. idem, values in percent; c. average numbers per core, layer by layer. Standard errors ( $P$ $<.05)$ reflect variations in average numbers between core samples over the rice field.

Fig. 3. Stratification des invertébrés dans une rizière de Camargue, le 4 juin $\left(\mathrm{t}_{2}\right)$ et le 15 juillet $1996\left(\mathrm{t}_{6}\right)$ : a. nombre total d'invertébrés (pour la composition détaillée de la biocénose se reporter à la Fig. 4); b. idem, valeurs en pourcent; c. effectifs moyens par carotte, strate par strate. L'erreur standard $(\mathrm{P}<0,05)$ illustre les variations d'effectifs entre les différents échantillons (hétérogénéité spatiale de la rizière).

teaux \& Marazanof (1965) is more advisable (Thiéry 1982).

The present method is used for the first time in standing freshwater. A quite similar technique has been recently used successfully in marine meiofauna by Fleeger et al. (1995), who used a 24 vertically sectionned core with a surface of $4.5 \mathrm{~cm}^{2}$, and $2 \mathrm{~mm}$ intervals. Although the cores used by Fleeger et al. (1995) were sli- ced more finely, our results present great similarities in the vertical profiles and invertebrate densities. However, although no definitive conclusion could be made given that we compare subtidal and freshwater sediments, these analogous results tend to prove that our stratified corer gives undisturbed cores and represents an useful complement to the quantitative water sampling method (open cylinder) in rice fields ecological 

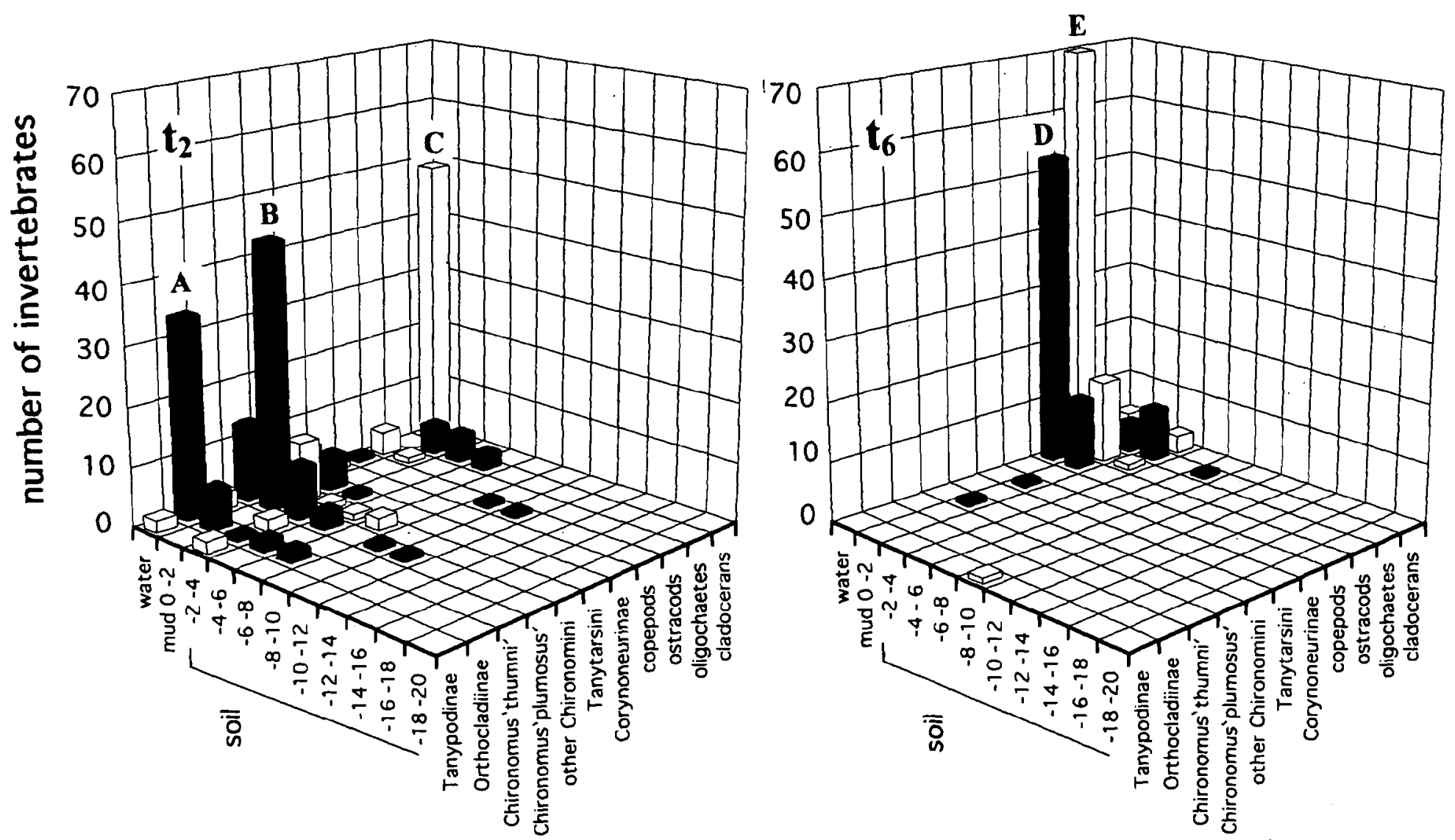

depth (in $\mathrm{cm}$ )

Fig. 4. Vertical profiles of the different biota recovered at the two sampling dates $t_{2}$ and $t_{6}$. At $t_{2}$, the letters A (chironomid Orthocladiinae larvae), B (Chironomus plumosus-group larvae) and C (cladocerans) indicate high density peaks. At $\mathrm{t}_{6}, \mathrm{D}$ (copepods) and $\mathrm{E}$ (ostracods) indicate high densities.

Fig. 4. Stratification des différents taxa aux dates de prélèvement $t_{2}$ et $t_{6} A t_{2}$, les lettres $A, B$ et $C$ indiquent respectivement les fortes densités de larves de Chironomidés Orthocladiinae, de larves de Chironomus gr. plumosus, et de Cladocères. $\mathrm{A} \mathrm{t}_{6}, \mathrm{D}$ et $\mathrm{E}$ indiquent les fortes densités de Copépodes et d'Ostracodes.

Total number of chironomid larvae (per $\left.10 \mathrm{~cm}^{2}\right)$

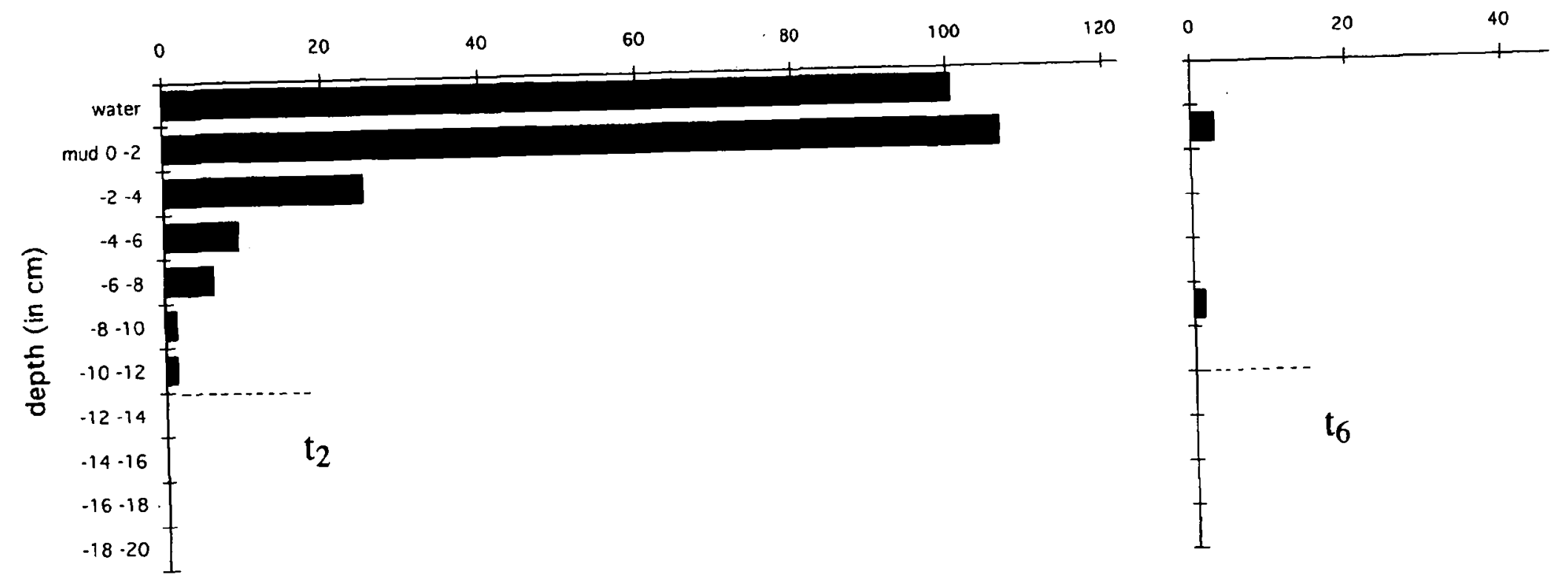

Fig. 5. Vertical profiles of total chironomid larvae at $t_{2}$ and $t_{6}$. Note the burying behaviour of larvae $\left(t_{2}\right)$ and the absence of populations at $t_{6}$. Fig. 5. Distribution verticale des larves de Chironomidés aux dates $t_{2}$ et $t_{6}$. Noter le comportement fouisseur des larves à $t_{2}$ et la disparition de la population à $t_{6}$. 
study. The vertical profile obtained in the present study also agrees with the data recovered from the sediments of a pyrenean mountain lake by Giani \& Lucas (1974).

This bottom sampler proved ideal for comparative vertical profiles in time (phenological studies). Moreover, in addition to its suitability for sampling benthic invertebrates, it proved to be well adapted to quantitative sampling of chironomid larvae, one of the main pests in Camargue rice fields. A study of the role of midge larvae and particularly its injury to rice growth will be published later.

\section{Acknowledgements}

We thank the workshop staff of the Sunn® entreprise (Saint Gaudens, France) and especially A. Vedere, for construction of the corer. We also thank J. P. Taris (Director of the Station Biologique de la Tour du Valat, Camargue) for the sampling authorization in the rice field. Thanks to J. Sanchez (Tour du Valat) for help in the field, and to E. Franquet (University of Aix-Marseille 3, Saint-Jérôme) for chironomid larvae identifications. Thanks to D. Defaye (Museum National d'Histoire Naturelle de Paris) for advice and critical review of the manuscript. This work was funded by the Agrobiology project U.P.R.E.S. - E.A. $\mathrm{n}^{\circ} 2.152$.

\section{References}

Aguesse P. 1955. - Note préliminaire sur les Odonates de Camargue. Terre et Vie, $4: 287-308+\mathrm{pl} .7$.

Armitage P. D. 1979. - A folding artificial substratum sampler for use in standing water. Hydrobiologia, 66 (3) : 245-248.

Crossland N. O. 1962. - A mud-sampling technique for the study of the ecology of aquatic snails, and its use in the evaluation of the efficacy of molluscicides in field trials. Bull. Wld. Hlth. Org., 27 : 125-133.

Darby R. E. 1962. - Midges associated with California rice fields, with special reference to their ecology (Diptera: Chironomidae). Hilgardia, 32 (1) : 1-206.
Douglas D. J. 1988. - A modified light weight piston corer for sampling soft lake sediment. Annls Limnol., 24 (2) : 193-196.

Downing J. A. 1984. - Sampling the benthos of standing waters. In A manual on methods for the assessment of secondary productivity in fresh waters. J. A. Downing and F. H. Rigler (eds.), IBP Hand Book 17, Blackwell Scientific Publications, $2^{\text {nd }}$ ed.: 87-130.

Fleeger J. W., Shirley T. C. \& McCall J. N. 1995. - Fine-scale vertical profiles of meiofauna in muddy subtidal sediments. Can. $J$. Zool., $73:$ 1453-1460.

Fuller C. M. \& Butman C.A. 1988. - A simple technique for finescale, vertical sectioning of fresh sediment cores. J. Sediment. Petrol., $58: 763-768$.

Giani N. 1974. - Description d'un nouveau type de carottier pour les sédiments très fluides. Annls Limnol., 10 (1) : 99-108.

Giani N. \& Lucas C. 1974. - Les sédiments d'un lac de haute montagne: structure, nature et peuplement. Annls Limnol., 10 (3) : 223-244.

Heurteaux P. \& Marazanof F. 1965. - Une méthode de prélèvement quantitatif en écologie aquatique. Annls Limnol., 1 (2) : 191-196.

Howmiller R. P. 1972. - Effects of preservatives on weights of some common macrobenthic invertebrates. Trans. Amer. Fish. Soc., $4: 743-746$.

Kellen W. R. 1954. - A new bottom sampler. Amer. Soc. Limnol. Oceanogr. Special Pub., 22 : 1-3.

MacCauley V. J. E. 1975.- Two new quantitative samplers for aquatic phytomacrofauna. Hydrobiologia, 47 (1) : 81-89.

Pont D. 1983. - Recherches quantitatives sur le peuplement de Copépodes, Cladocères et Ostracodes des rizières de Camargue. Thèse Doctorat es Sciences, Université d'Aix-Marseille 1:362 p.

Senapati B. K. \& Dash M. C. 1980 . - Effect of formalin preservation on the weight of tropical earthworms. Rev. Ecol. Biol. Sol, 17 (3) : 371-377.

Southwood T. R. E. 1978.-Ecological methods with particular reference to the study of insect populations. $2^{\text {nd }}$ ed., Methuen \& Co LTD, London : $355 \mathrm{p}$.

Thiéry A. 1982. - Hydrobiologie d'un complexe palustre de Crau; les marais du Plan du Bourg (Bouches-du-Rhône, France). Structure des écosystèmes et dynamique des communautés d'invertébrés aquatiques. Annls Limnol., 18 (2) : 151-171. 